This PDF is a selection from a published volume from the National Bureau of Economic Research

Volume Title: Organizations, Civil Society, and the Roots of Development

Volume Author/Editor: Naomi R. Lamoreaux and John Joseph Wallis, editors

Volume Publisher: University of Chicago Press

Volume ISBNs: 978-0-226-42636-5 (cloth); 0-226-42636-X (cloth)

Volume URL: http://www.nber.org/books/lamo14-1

Conference Date: October 24-25, 2014

Publication Date: November 2017

Chapter Title: Pluralism without Privilege? Corps Intermédiaires, Civil Society, and the Art of Association

Chapter Author(s): Jacob T. Levy

Chapter URL: http://www.nber.org/chapters/c13510

Chapter pages in book: (p. $83-108)$ 


\title{
Pluralism without Privilege? Corps Intermédiaires, Civil Society, and the Art of Association
}

\author{
Jacob T. Levy
}

\subsection{Competition, Integration, Opposition}

The decades of the mid-eighteenth through the mid-nineteenth centuries span the emergence of fully liberal political and social theory, and an early version of liberal practice, in France, the United Kingdom, and the United States. In political theory, elitist Whig and civic republican ideas about virtue - skeptical of commerce, political parties, and religious divisiongave way in fits and starts to ideas that were both more egalitarian and more pluralistic. Commercial markets, competitive electoral democracy, and religious liberty came to occupy pride of place in theories about free social orders. $^{1}$

Political practice did not start in the same place - in the early eighteenth century civic republicanism and country Whig ideology were languages of criticism, not apologies for the status quo. But the theoretical transformation came to converge in meaningful part with changes in practice. Sometimes theory probably led practice, as in the development of religious liberty. Sometimes practice probably led theory, as theorists noticed new features

Jacob T. Levy is the Tomlinson Professor of Political Theory at McGill University.

Thanks to Emma Rothschild, John Wallis, Naomi Lamoreaux, Paul Dragos Aligica, Deborah Boucoyannis, David McIvor, Abraham Singer, and audiences at the 2015 Annual Meeting of the Association for Political Theory and at Texas A\&M University and the King's College London Department of Political Economy for comments and suggestions. Kelsey Brady provided valuable research assistance, supported by the Arts Research Internship Award at McGill University. This research was supported by an Insight Grant from the Social Sciences and Humanities Research Council of Canada. For acknowledgments, sources of research support, and disclosure of the author's material financial relationships, if any, please see http:// www.nber.org/chapters/c13510.ack.

1. See Wood (1969), Pocock (1975), and Kalyvas and Katznelson (2008). I discuss this transformation further in Levy (2006). 
of an emerging social order, and came to understand what might be attractive about them. Often, they reinforced one another. The doux commerce theorists observed economic changes that were already under way, but their theoretical redescriptions of them supported legal and political changes that could support or even accelerate them.

This liberalization in part consisted of substantive policy changes: increased religious liberty and freedom of the press, for example. And it in part consisted of major changes in the politics that generates and maintains policies. Sometimes these reinforced each other in a virtuous spiral. North, Wallis, and Weingast have argued that this happened with the democratization of organizational tools that had previously been open only to members of the elite: the shift from specially chartered monopolistic corporations to general incorporation laws, and from parliamentary oligopolistic party competition to modern parties competing in wide-suffrage elections. ${ }^{2}$ These new "open-access" orders found a secure foundation for generalized associational and commercial liberty by overcoming the system that confined politics to intraelite rent-seeking competitions.

The liberal political and social theorists who lived through the era had serious doubts that the new democratized politics could successfully support the new liberalized policies. In this chapter I hope to make their argument accessible, first in a generalized way and then through a reading of four key thinkers. They looked forward to the possibility of a pluralism without privilege, but had doubts about its sustainability. They offered some reasons to prefer pluralism with privilege to the absence of both. They worried that centralization, democratic or otherwise, might be the preeminent fact of modern state consolidation, and that purely voluntary, equal, associational pluralism might not be powerful enough to check it. The kinds of pluralism grounded in ancien régime privilege and status, in entrenched jurisdictional pluralism within the constitutional order, or in pre-political cultural and customary ties might be needed to motivate the oppositional political action that could protect pluralism and freedom.

I begin with three simplified ways of thinking, deliberately stylized and abstract, about the relationships among intermediate bodies and between them and the larger society. These do not necessarily describe different types of groups or different legal regimes governing group life; the same groups might interact with each other or with the larger society in any or all of them. They do, however, draw our analytical attention to different features of pluralistic social orders.

First, and perhaps most typical of open-access orders, groups and associations might be thought of as competitive with one another, analogously to the competitive character of incorporated firms in an open market under laws of general incorporation. The associations that exist, and their rela- 
tive success, represent the choices made by members who have the right to form, join, and exit groups relatively easily. Universities and private schools compete for students and teachers; religious denominations under conditions of religious freedom compete for adherents; municipalities compete for residents and capital through Tiebout sorting and as the kind of agents in a polycentric order analyzed by Elinor and Vincent Ostrom; ${ }^{3}$ and political parties compete for votes and members. Different activist groups devoted to the same issue, or different recreational or fraternal clubs of the same type, might compete with each other as well. Competitive groups are similar enough, with members who are similar enough, to be meaningfully rivalrous; a church is not competitive with a municipality or a bowling league. When we think of groups as competitive, we emphasize not only their similarity but also their horizontal relation: cities compete with cities, not with provinces or with neighborhoods. Competitive associational life, of course, relies in part on the kind of "exit" described by Albert Hirschman, but that feature is easily overstated; exit might happen only at the margins and yet exert important disciplining effects on groups that are otherwise characterized by a great deal of loyalty and voice. ${ }^{4}$ Voters do not desert their political parties as easily as consumers do a product brand, and residents are not quick to move out of their cities, but in both cases the possibility creates a competitive dynamic nonetheless.

This competitive understanding of intermediate groups is congenial to the analysis of the open-access order found in North, Wallis, and Weingast. It also figures prominently in Ernest Gellner's account of civil society, an order populated by "modular man" who can leave one group and join another without essential change in his identity or status. ${ }^{5}$ Gellner influentially argued that civil society so conceived, not democratization or capitalism, was the key to the breakthroughs of western modernity. The social world of many fluid, overlapping, and competing horizontal organizations offered a superior, freer, model than the purposive unity of whole polities, or than centralized command-based absolutism, or than segmentary and tribalistic social orders. This liberal pluralism, he thought, had allowed the emergence of democratic market societies in the first place, and was the key to establishing them or reestablishing them in the post-Cold War world.

Second, group life might be thought of as an integrative phenomenon. In the service of common and overarching ends, there is value in local participation and the sense of personal agency that comes from being part of a subgroup, and so smaller groups can be a way of drawing their members into overarching ones. Here the analytical emphasis is vertical, not hori-

3. See, for example, Ostrom (1990), Ostrom, Tiebout, and Warren (1961), Tiebout (1956), and compare Weingast (1995).

4. Hirschman (1970).

5. Gellner (1994). 
zontal, and relations among groups and the same kind at the same level is comparatively unimportant. A variety of groups at the same horizontal level are often, in integrative models, drawn together into the larger whole. But their plurality is not in itself the point; they are only the local, visible, accessible aspect of a larger whole. Each parish might have its own school and its own poor relief as the instantiation of communal projects of education and charity. Each town in an administratively decentralized unitary state might have its own local officials who implement the centrally decided policies. In belonging to the local group, members also belong to the larger one, and take part in its activities.

Integrative group life, in which groups interact as parts and wholes, cooperatively rather than competitively, is perhaps most widely known in social theory through the doctrine of subsidiarity in Catholic social thought. ${ }^{6}$ Subsidiarity emphasizes the importance of local decisions and actions, of local group life, within the context of an organically integrated whole community, whether the church as such or social life more generally. In a different intellectual tradition, the corporations that mediate citizenship in Hegel's Philosophy of Right are organized by industry and profession, with no mention of or apparent value in having (say) competing corporations of lawyers. Members belong to a corporation or estate and, through that, to the state.

The "deep diversity" advocated by Charles Taylor" - at once perhaps the leading living Catholic political philosopher and the leading living Hegelian political philosopher - treats smaller units as ways of belonging to the larger. These need not all represent the same way of belonging. Quebec, in Taylor's vision, represents a different mode of belonging to Canada, a substantively different type of membership in the federation, from the other provinces. But that does not mean that the other provinces lacking that distinctiveness should be abolished, only that they do not mediate membership in Canada in the same thick way that Quebec does. In any case, the question for everyone is "how do we belong to Canada?," that is, how do our intermediate groups mediate our membership in the larger whole?

If competitive associations can be compared to competitive firms, the political economy analogue of integrative associational life is corporatism, as in the postwar economic model in some European countries wherein encompassing organizations representing labor and capital negotiated nationwide agreements with the help of a government concerned with the whole economic system. ${ }^{8}$ In corporatism as in subsidiarity, organizations are actually nested. But the integrative way of looking at group life does not require this. The so-called neo-Tocquevillian studies of associational life associated with Robert Putnam also emphasize belonging to associations

6. Golemboski (2015).

7. Most famously in Taylor (1992). See also "Shared and Divergent Values," in Taylor (1993).

8. Schmitter (1974). 
as a way of belonging to a larger social whole, united by bonds of trust and building social capital for the benefit of the whole community. ${ }^{9}$

Third, we might think of group life as oppositional. If the competitive model emphasizes horizontal rivalry, and the integrative model emphasizes harmonious vertical nonrivalry, the oppositional model emphasizes vertical rivalry: our local or particular or intermediate group offers the possibility of dissent, difference, or resistance. ${ }^{10}$ The church provides its members with social norms that meaningfully differ from those of the wider society, and the organizational resources with which to defend their religious liberty against state intrusion. Any type of adversarial federalist theory - the intercession theories of the Kentucky and Virginia Resolutions, the rivalry for loyalties between states and center envisioned in Federalist numbers 45-46, the Hapsburg-inspired multinational federalism defended in Lord Acton's On Nationality - uses these lenses, emphasizing not that (e.g.) Quebec is how I belong to Canada, but rather that it is how I sometimes do not, that it is the place where I can stand when I wish to say no to Canada. ${ }^{11}$ Dissenting churches under religious establishment obviously lend themselves to this kind of analysis, but orthodox or established churches can too, when they have enough institutional weight to counterbalance decisions made by political elites and state actors. An oppositional stance is relative to another group or set of groups. The medieval walled city might be oppositional relative to the local lord but integrative with political order of the kingdom as a whole; the walled university or the church giving sanctuary might be oppositional relative to the city.

With these three models in mind, it would be easy to think of the emergence of liberalism, of civil society in the contemporary sense, and of openaccess orders as being a matter of the replacement of integrative and oppositional styles of group relations with a competitive model. I hope to show that matters were, and remain, more complicated than that. I will draw on theorists who lived through the transition to early open-access societies to suggest that the competitive mode of group relations might not be selfsufficient. The open-access order may remain dependent on institutional inheritances and forms from what North, Wallis, and Weingast term the

9. See, especially, Putnam (2000).

10. This typology obviously omits one category: horizontal nonrivalry. This suggests cartelism in political economy, or rigid segmented communalism in group life such as the millet system in the Ottoman Empire, or perhaps some kinds of confederalism in government structures. It is the "segmented society" discussed by Gellner as a contrast to civil society. I mention it here for completeness. It does not, however, play much part in the debates surrounding the emergence of the liberal order, save perhaps in some early discussions of American federalism, and I do not discuss it further.

11. In Levy (2007), I discussed some of these cases in the context of offering an oppositional understanding of federalism, distinct from both competitive federalism and subsidiarity, though I did not use the competitive/integrative/oppositional typology or draw the connections to questions of associational life and civil society. See Lord Acton, "On Nationality," in Fears (1988). 
"mature natural state," "characterized by durable institutional structures for the state and the ability to support elite organizations outside the immediate framework of the state," ${ }^{\prime 2}$ in order to undergird, in particular, pluralism of the oppositional type.

The general argument that appears over the course of most of a century has two main parts. First is the claim that (at least in the postmedieval era) there is a general tendency for states to become more centralized, and a corresponding temptation on the part of those who wield state power to impose uniformity across the territory they govern. This, so it is argued, makes pluralism of all kinds vulnerable. Second is the idea that only some kinds of group life are generative of an oppositional politics that can keep that tendency in check. These are, especially, those that have a strong extrapolitical motivational claim on their members, from aristocratic honor to religious commitment to provincial or linguistic-national loyalty. The recurring worry is that even such motivations will not suffice to support the needed oppositional work, if group members do not have the added motivation and added political resources that come from institutionalized status or privileges.

\subsection{Montesquieu, Corps, and Uniformity}

Montesquieu's 1748 The Spirit of the Laws famously identified corps intermédiaires as the crucial constitutional pillars of a moderate monarchy. ${ }^{13}$ Montesquieu treated the self-government of cities, provinces, guilds, and the church as a part of the defense of limitations on centralized state power, the kinds of limits that were sorely needed in the era of would-be absolutist kings. The argument depended in part on the quasi-public or public character of the corps: their privileges made up part of the constitutional order. And it depended in part on their base in extralegal social facts not susceptible to direct royal intervention, such as the nobility's attachment to their honor and the independent belief system that animates the church. Montesquieu's was an oppositional pluralism that drew its strength from privilege; drawing on their respective social bases of support and appealing to law, the corps could limit monarchies and prevent them from degenerating into despotism. ${ }^{14}$

Montesquieu distinguished moderate monarchies and immoderate despotisms on the basis of the former's respect for the corps. "Intermediate,

12. North, Wallis, and Weingast $(2009,47)$. They add "at the limit, a mature natural state is able to create and sustain perpetually lived organizations, but that is not a common feature of mature natural states." Common or not, the perpetually lived organizations with independent legal personality, the corps with corporate form, were very much a feature of the mature natural states that we find in early modern, pre-Revolutionary Europe. Since the theorists I discuss here take the possibility of the corps for granted, I will not discuss the alternative of mature natural states that lack them. See also North, Wallis, and Weingast (2009, 158-69).

13. Montesquieu ([1748] 1989).

14. Sections 3.2-3.4 draw on Levy (2015). 
subordinate, and dependent powers constitute the nature of monarchical government, that is, of the government in which one alone governs by fundamental laws." 15 The "lords, clergy, nobility, and towns" maintain a monarchy in its proper conceptual form. The most "natural" intermediate power is the nobility as a class, so much so that "nobility is the essence of a monarchy, whose fundamental maxim is: no monarch, no nobility; no nobility, no monarch; rather, one has a despot." Even the church, which he sharply criticizes for intolerance and persecution, has a crucial role to play, and he suggests that ecclesiastical autonomy should be respected and legally firmly established. It provides the final check against despotism when a monarchy has otherwise abolished all of its old laws. This is, importantly, a defense of the nobility in a monarchy, not of nobles as such. The aristocracy in a monarchy defends the laws; aristocratic government without a monarch to overawe the nobles tends toward arbitrariness and corruption. Their privileges are "odious in themselves" - a view that will persist throughout the theorists discussed below - but instrumentally useful in aligning their honor with the defense of the constitution. ${ }^{16}$

The continued freedom of the corps was a visible sign of a monarchy's continued adherence to lawful limits, but it was not only that. Montesquieu held that monarchies could only remain moderate and lawful regimes over time because of the continued existence of the corps. As their liberties and privileges diminished, the monarchy would slip farther and farther toward despotism. This was because only the corps could have both the motivation and the power to successfully check the urge of monarchs to absolutism. Without them, there is no one who can refuse the king, particularly not in the name of law. Of special importance are those intermediate bodies he calls the "depositories of the laws" as they will have a special connection with the retention and enforcement of legality and liberties: in France, the aristocratic courts known as parlements, which even in their weakened eighteenth-century state "do much good." 17

Montesquieu admired the British constitution, the subject of extended discussions in II.11 and III.19. But his enthusiasm for England's system was limited precisely by the decline of England's corps since the Civil War. "If you abolish the prerogatives of the lords, clergy, nobility, and towns in a monarchy, you will soon have a popular state or else a despotic state [. . . In order to favor liberty, the English have removed all the intermediate powers that formed their monarchy. They are quite right to preserve that liberty," he drily concludes; "if they were to lose it, they would be one of the most enslaved peoples on earth" because of their abolition of intermediate powers. ${ }^{18}$

15. Montesquieu ([1748] 1989, II.4, 17).

16. Montesquieu ([1748] 1989, II.11.6, 161).

17. Montesquieu $(2012,192)$.

18. Montesquieu ([1748] 1989, II.4, 18-19). 
The conviction that the corps, including those staffed by hereditary nobility, are crucial to the maintenance of a lawful and balanced monarchy helps to explain Montesquieu's apparently odd identification of honor as the animating principle of a monarchy. Aristocratic honor, after all, does not derive directly or solely from the monarch, but rather from a sense of the dignity and respect that is due as a matter of family standing and personal merit. For aristocrats who are drawn to court, that is, Versailles, the monarch has an outsized influence on their status and standing. But those driven by honor could not be the kinds of subservient flatterers demanded by despots. They could not help but stand up for the dignity of their own offices and authority. Indeed, they could not even be counted on to obey direct royal commands: aristocratic officers had been known to disobey orders that we would think of as war crimes but that they construed as dishonorable. However poorly justified a person's view of his own honor might be, it remained his, not only outside the direct control of the monarch but sometimes a psychological source of the willingness to resist him. ${ }^{19}$ If the corps were needed to affirm and enforce legal limits on royal power and prevent despotism, honor or some other extralegal motivation was needed to animate the corps, and to keep their members dedicated to their defense. This is why, notwithstanding the "ignorance natural to the nobility, its laxity, and its scorn for civil government, ${ }^{, 20}$ it is the sine qua non of lawful and moderate monarchy.

Montesquieu critiqued the turn to absolutism and centralization under Louis XIV, albeit always with a slight, politic opacity. The recurring comparisons and contrasts between monarchies and despotisms often come just to the edge of saying that Bourbon France had crossed, or risked crossing, the line between them. The corps had been steadily undermined in "a great European state" over the preceding centuries. "In certain European monarchies," the autonomous provinces that govern themselves well and thus thrive are constantly threatened with the loss of "the very government that produces the good," to better allow them to "pay even more." 21 This strategy of killing the golden goose is another sign of despotism; "when the savages of Louisiana want fruit, they cut down the tree and gather the fruit. There you have despotic government." 22

Montesquieu added to his political and constitutional critique of despotic uniformity an understanding of a social world autonomous of, and not created by, political rule. Geography and climate, historical and cultural change, economic forces, and religion all constrained in various ways what rulers

19. For discussions of honor as a source of strength for political resistance, though in a more democratic spirit, see Krause (2002) and Appiah (2010).

20. Montesquieu ([1748] 1989, II.4, 19).

21. Montesquieu ([1748] 1989, II.13.12, 221). For an account of Montesquieu's defense of provincial autonomy that amounts to a kind of federalist constitutionalism for monarchies, see Ward (2009).

22. Montesquieu ([1748] 1989, I.5.13, 59). 
could do - and in different ways in different places. He advises legislators and rulers to notice the particularities of their societies and govern accordingly, rather than in accordance with abstract plans. Like his followers for the rest of the eighteenth century - social theorists studying manners and mores, classical economists elaborating an economic world that transcended political boundaries and operated according to its own discoverable rules Montesquieu sought to describe societies rather than simply polities, and societies that shaped and constrained the polities set over them. ${ }^{23}$

Near the end of The Spirit of the Laws, in the midst of an extended constitutional history of France, we find a surprising chapter on the idea of uniformity of laws, against which Montesquieu warns the would-be legislator:

"There are certain ideas of uniformity, which sometimes strike great geniuses (for they even affected Charlemagne), but infallibly make an impression on little souls. They discover therein a kind of perfection, which they recognize because it is impossible for them not to see it; the same authorized weights, the same measures in trade, the same laws in the state, the same religion in all its parts. But is this always right and without exception? Is the evil of changing constantly less than that of suffering? And does not a greatness of genius consist rather in distinguishing between those cases in which uniformity is requisite, and those in which there is a necessity for differences? In China the Chinese are governed by the Chinese ceremonial and the Tartars by theirs; and yet there is no nation in the world that aims so much at tranquility. If the people observe the laws, what signifies it whether these laws are the same?"24

Near the beginning of the book Montesquieu had said that when a ruler "makes himself more absolute, his first thought is to simplify the laws." 25 Then, it had appeared as something like a deliberate strategy, as the simplified state would be simpler to rule. But at the end of the book it appears rather as an unjustified taste or a psychological affliction of those who hold power or make laws. Shortly before the remarks on uniformity, he wrote that "it seems to me that I have written this work only to prove [. . .] that the spirit of moderation should be that of the legislator; the political good, like the moral good, is always found between two limits." ${ }^{26}$ But the spirit of moderation was not normally or naturally that of the legislator.

While Montesquieu's multistranded defense of pluralism and the privileges of the corps were highly influential through the eighteenth century, two rivals to it were as well. One, the civic republican suspicion of factions, was associated with Rousseau, Mably, and Sièyes as well as with important strands in the American and French Revolutions. The elevation of extrale-

23. This is the sense in which Durkheim saw Montesquieu as one of the founders of sociology, set apart from political philosophy. See also Taylor (1990).

24. Montesquieu ([1748] 1989, VI.29.18, 617).

25. Montesquieu ([1748] 1989, I.6.2, 75).

26. Montesquieu ([1748] 1989, VI.29.1, 602). 
gal social pluralism into a public constitutional fact became identified with both intolerable privilege and illegitimate disunity. The other, a rationalistic individualism, looked forward to the use of modernized state power to check or abolish the corps, not backward toward imagined pasts of uncorrupted unity. It is in principle distinguishable from the civic republican view, most prominently by its greater enthusiasm for commerce but also by its greater tolerance for associational pluralism provided that privilege was stripped away. The gradual shift from a civic republican suspicion of all factions in politics to a pluralist view that competitive factions (and, later, parties) might be attractive and necessary features of republican politics is well known. And there is, I suspect, something to be said for the idea that this shift corresponds with (and contributes to) that from regulated intra-oligarchic contestation to the early open-access orders of the nineteenth century.

In the remainder of this essay, however, I follow an intellectual path from Montesquieu onward. Montesquieu and his successors wanted no part of the civic republican obsession with unity, but the pluralism they espoused was never only that of freely created associations peacefully competing. Although Smith, Constant, and Tocqueville did value competitive associational life, they also followed Montesquieu in his attention to oppositional pluralism - and they offered reason to think that oppositional pluralism might require deeper social roots than open access and individual consent could provide.

\subsection{The Man of System and the Religious Marketplace}

One of the first powerful analyses of associations as competitors appears in The Wealth of Nations' treatment of religious groups. ${ }^{27} \mathrm{It}$ is, of course, not a coincidence that this analysis is offered by Adam Smith, in the course of a work that shows the beneficial consequences of competitive behavior in a range of domains and that is remembered as the key intellectual defense of free economic competition against oligarchic mercantile monopolies. His treatment in Book V of vibrant competition among churches for members, however, is surprisingly dissimilar to his examinations of marketplace behavior in Books I and II. His is not a model of parishioners casually shopping from one church to another at arm's length, but of believers being provided with community, structure, and meaning by sects that might counteract the anonymity and alienation of modern urban life.

The discussion is framed in part as a reply to David Hume's wry defense of an established church, an argument in favor of indolent salaried priests as against the tendency of a free religious marketplace to favor passionate religious enthusiasm and the sects that march a population toward religious civil war. Smith agrees with Hume that energetic and excessively rigorous 
churches will have a competitive advantage over their distant, lazy, bureaucratic counterparts. (Not to put too fine a point on it: they both saw the rise of Methodism at the expense of traditional Anglicanism as recalling the earlier rise of Puritanism, and as examples of a general truth about religious competition.) He importantly disagrees about the political conclusion, arguing that in the absence of establishment, religious competition tends to multiply sects and to create diffuse contestation, not the concentrated type that can lead to civil war. Indeed, he blames the established bureaucratic churches, not their passionate opponents, for civil wars; it is the establishment that makes use of state power and elevates disagreement into organized violence. The critique of established churches resembles that of mercantilist monopolies: the privileged and powerful make illegitimate use of the state and entrench their own advantages. But his model of competitive behavior among the sects does not much resemble that of his understanding of marketplace behavior. Indeed, the anonymous and arm's-length character of market and city life partly creates the need that passionate sects fulfill: a need for intense community based on strong emotional connection and mutual knowledge. Whereas commerce is generally a mild and moderating force in Smith's thought, moderation is precisely what does not result from religious competition. Competition does not turn religious life into something calm and rational, deliberately chosen and deliberately exited from. Rather, it changes the institutional setting for our expression of deep commitments, and can thereby serve valuable social functions (relief from anonymity, mitigation of social and moral decay in the city) rather than creating political dangers.

And this attention to the deep attachments we hold to our identities and memberships sometimes pushed Smith from a competitive to an oppositional understanding of pluralism, as in his indictment of the "man of system" in the final edition of The Theory of Moral Sentiments, published during the early stages of the French Revolution. ${ }^{28}$ Its best-known lines have sometimes been read as if they were criticisms of centralized economic planning and treated as a kind of adjunct to The Wealth of Nations.

"The man of system, on the contrary, is apt to be very wise in his own conceit [.. .] He seems to imagine that he can arrange the different members of a great society with as much ease as the hand arranges the different pieces upon a chess-board. He does not consider that the pieces upon the chess-board have no other principle of motion besides that which the hand impresses upon them; but that, in the great chess-board of human society, every single piece has a principle of motion of its own, altogether different from that which the legislature might chuse to impress upon it."

In fact, the passage concerns constitutional reform, privilege, and politics, not economics at all. Smith's man of system bears a closer resemblance to 
Montesquieu's legislator of uniformity than to the modern would-be economic planner. In his desire to abolish privilege, the man of system proposes "to new-model the constitution, and to alter, in some of its most essential parts, that system of government under which the subjects of a great empire have enjoyed, perhaps, peace, security, and even glory, during the course of several centuries together." In seeking to implement the far-reaching reforms that appear in his mind as uniform, symmetrical, and beautiful, the man of system holds special fury for those elements of society that might have the constitutional power to obstruct them. "The great object of their reformation, therefore, is to remove those obstructions; to reduce the authority of the nobility; to take away the privileges of cities and provinces, and to render both the greatest individuals and the greatest orders of the state, as incapable of opposing their commands, as the weakest and most insignificant."

By contrast, "the man whose public spirit is prompted altogether by humanity and benevolence, will respect the established powers and privileges even of individuals, and still more those of the great orders and societies, into which the state is divided. Though he should consider some of them as in some measure abusive, he will content himself with moderating, what he often cannot annihilate without great violence."

In other words, while Smith sees that the differential privileges of the "orders and societies," the nobles, provinces, and cities, are often abusive ("odious in themselves," as Montesquieu put it), he also thinks that they serve as a valuable political and constitutional counterweight to centralized and rationalizing power. The wise reformer would seek to mitigate the abuses but not to abolish the special constitutional standing.

While the monopolistic privileges of an established church or of the mercantile companies normally tend to augment unitary central power, the constitutional privileges of a plurality of cities, provinces, or nobles can be quite different. Just as Montesquieu had seen, their various bases of independent social power mean that they are in a good position to oppose abuses on the part of the state itself, whether committed by "imperial and royal" centralizers or by the leaders of revolutionary factions.

Smith's discussion of the man of system includes the idea of competitive political parties of a sort - and party competition is the problem, not the solution. Moderate reform is less likely to appeal to the passionate partisan base than is wholesale abolition; even party leaders who know better may be radicalized by the competitive dynamic. And the bodies he names as moderating forces, the "orders and societies," could not be created by associational free competition: provinces are not clubs, and nobles are not a party. They are limited in number, privileged, and rest on or engender very particularistic commitments on the part of their members.

In Smith we thus see a crucial range of treatments of pluralism, which includes not only the kind of competitive behavior among firms that we most associate with competition in open-access orders, but also the passionate 
and particularistic competition among churches, and an oppositional status of privileged pluralistic orders. His appreciation for the value of something very like open access in the spheres of the market and religion coexisted with a not-entirely-grudging tolerance for the constitutional institutions of the mature natural state.

\subsection{Constant's Pluralism}

Benjamin Constant was the first major political theorist to call his thought "liberal" and to identify with liberalism as a party position. While we might think of Adam Smith as the most important exponent of a theory of openaccess markets, and James Madison as the crucial figure in developing an account of factional political competition through electoral politics, Constant is the first theorist of the emerging liberal order as a whole: freedom of religion, speech, and the press; due process of law and equality before the law; competitive and responsible representative democracy; free markets and free trade; and the elevation of individual private liberty to a privileged moral position. He famously opposed Rousseau's democratic holism and celebrated modern individuality. He could see the possibility of competitive pluralism without privilege, and he welcomed it. But he shared many of Montesquieu's and Smith's worries, as well.

Much of Constant's writing on associational pluralism embraced competitive models, and defended group life as an aspect of individual freedom in the private sphere; and his instincts were always opposed to group privilege. Like Smith, indeed in very similar terms, he wrote sharply against guilds and exclusive corporations and in support of market liberalization..$^{29}$ In religion he supported the proliferation of sects and denominations as a positive good, and as in any case inevitable wherever persons cared about religious questions enough to think about them, rather than mindlessly following empty rituals. Schism and proliferation tended - through competition - to improve the moral purity of all sects, as the Reformation improved a previously corrupt Catholicism; and it also conduced to civil peace. ${ }^{30}$ His religious sensibility was a romantic Protestant individualism. ${ }^{31} \mathrm{He}$ was instinctively unsympathetic to Catholicism and skeptical of all sacerdotal corporations: organized churches, a privileged priesthood, and monastic orders. The religion to which he was so concerned to preserve free access was a religion of individual spirituality that develops the soul and the mind.

Yet he recognized that for many people their religious sentiments came to be tied up in external "forms," and that this was a reason for freedom of religious practice with respect to those forms - a freedom that had been 
violated under the Revolution. However little he liked them, he supported the liberty to form and live in associations such as monasteries. Provided that freedom of exit was protected, life within them was an option legitimately open to free persons. "There are two ways of suppressing monasteries; you may open their doors; or you may drive out their occupants. If you adopt the first solution, you do something good without causing any harm; you break chains without violating refuges. If you adopt the second, you upset calculations based upon public faith; you insult old age, which you drag languishing and unarmed into an unknown world; you violate an incontestable right of all individuals in the social state, the right to choose their own way of life, to hold their property in common, to gather in order to profess the same doctrine, to enjoy the same leisure, to savour the same rest." ${ }^{32}$

These religious cases were of central importance to Constant, and they offer reason to think that he might have viewed group life competitively: break the chains, let the sects proliferate, open the doors, let believers choose. Certainly he opposed the integrative style of thinking of the Catholic Church as providing believers with their way of belonging to France. And often he emphasized that the pluralism of group life was tightly connected to the ordinary private liberty of living as one chooses, including in customary ways. In his most enduring work of political theory, "The Liberty of the Ancients Compared with That of the Moderns," he held to the view that "the changes brought by the centuries require from the authorities greater respect for customs, for affections, for the independence of individuals." ${ }^{33}$ Habits and affections are a crucial part of a free person's happiness and, therefore, of his or her interests. In social life, particularly but not only in religion, the liberty of the moderns was closely tied to pluralism. Free people, not joined together by ancient republican devotion to the public, would not be socially homogenous.

But, like Smith, Constant drew on the oppositional style found in Montesquieu when it came to pluralism in the constitutional order. ${ }^{34}$ In the wake of a generation of Jacobin and Bonapartist centralization, Constant pointed to Montesquieu's insight about the perils of the spirit of uniformity. He argued both against the spirit of system that accompanies and initiates governors' desire to rationalize, and in active defense of the sentiments that attach

32. "On innovation, reform, and the uniformity and stability of institutions"; chapter 1 of the material added to the fourth edition of Conquest and Usurpation; Constant ([1819] 1988, 153).

33. Constant, "Liberty of the Ancients Compared with that of the Moderns" ([1819] 1988, 324).

34. More so than Smith, Constant drew directly on Montesquieu throughout his writings. "What a keen and profound eye!" he wrote in his diary. "All that he said, even in the smallest things, proves true every day." Constant, “Journaux Intimes," Jan. 28 ([1804] 1957). As Jeremy Jennings puts it, the argument for "the preservation of local independence as a means of restricting the power of despotic, central government" that Constant established as a central theme of French liberalism "was an updated supplement to Montesquieu's defence of the rights of the provincial nobility" (Jennings 2011, 164). 
people to their local traditions and rules. The desire to create order and rationality in society need not be destructive in itself; but it is too-easily joined with coercive force, as governors imagine that a uniform society will be more easily governed. "The spirit of system was first entranced by symmetry. The love of power soon discovered what immense advantages symmetry could procure for it." ${ }^{35}$ A kind of philosophical aesthetic motivated benevolent legislators in the first instance; but the desire for uniformity led to the destruction of the corps and nonstate institutions, enhancing the relative power of the center and creating a dynamic that outraced that initial publicspirited impulse. With Montesquieu and against such uniformity-craving philosophes as Voltaire, he wrote sympathetically about the provincial variety of laws in the old regime. ${ }^{36}$ The plurality of public jurisdictions and legal traditions attached people's natural sentiments of familiarity and home to the constitutional order. Rationalization from the center broke that tie.

Constant indicts the tendencies toward uniformity of centralized and metropolitan legislatures. The members of the latter tend to acquire an esprit de corps, identifying with each other and with the capital. So they "lose sight of the usages, needs, and way of life of their constituents. They lend themselves to general ideas of leveling, symmetry, uniformity, mass changes, and universal recasting, bringing upset, disorder, and confusion to distant regions. It is this disposition we must combat, because it is on particular memories, habits, and regional laws that the happiness and peace of a province rest. National assemblies are scornful and careless with these things." ${ }^{\prime 37}$ The better course is to allow the cities and provinces to keep their natural hold on our affections. "The interests and memories that arise from local customs contain a germ of resistance that authority is reluctant to tolerate and that it is anxious to eradicate. It can deal more easily with individuals; it rolls its heavy body effortlessly over them as if they were sand." ${ }^{38}$ That "germ of resistance" seems to me the crucial idea that runs throughout Constant's writings on pluralism and constitutionalism: the oppositional relationship between the various customary local jurisdictions and groupings on one hand, and the central state on the other.

During his years of exile from Napoleonic France, Constant worked on (but never finished) a book on the possibility of republican government in a large state, a possibility Montesquieu famously denied and one that Constant was at pains to establish. This work, dedicated to refuting one of the best-known of Montesquieu's arguments, is nonetheless steeped in Montesquieu's intellectual style and ideas. Constant understood that Mon-

35. Constant, "On Uniformity," in The Spirit of Conquest and Usurpation and Their Relation to European Civilization ([1814] 1988, 74).

36. Constant, Conquest and Usurpation ([1814] 1988, 154).

37. Constant, Book XV ch. 4, "Application of This Principle to the Composition of Representative Assemblies" ([1810] 2003, 328).

38. SCU, 74. 
tesquieu's skepticism was not aimed at the idea of freedom in a large state but at the idea of freedom in a republic. He thought that Montesquieu had looked at the virtuous, anticommercial, unfree republics of antiquity and attributed those features to republics, when they were better attributed to the ancient era as such. ${ }^{39}$

This was Constant's position throughout his life: that freedom was possible in a large and extended republic, and that much that Montesquieu attributed to the spirit of a nation or of its laws is in fact attributable to the spirit of the age. Constant's political agenda never included the recreation of the ancient constitution of Montesquieu's time. But he sympathized with Montesquieu's defense of that constitution and tried to draw appropriate lessons from it; he did not view it as a defense of local tyranny and arbitrariness. On the central claim that intermediate bodies, a hereditary class, and corporations were essential for freedom, Montesquieu had been right to see them as the bulwarks of freedom against the king of his era. Their irrationality and inegalitarianism did not condemn them out of hand; uniformity under a tyrannical law was, for Constant as for Montesquieu, no virtue. The task for republican and post-Revolutionary thought was, in part, to find ways to recapture the pluralistic benefits without the abusive privilege.

Constant criticized the idea of hereditary rights of rule and the existence of a hereditary principle in a constitution. But his understanding of Montesquieu's defense of such things was that under an "abusive" government, "heredity can be useful; where rights have disappeared, privileges offer asylum and defense. In spite of its inconveniences, heredity is better than the absence of any neutral power. The hereditary interest . . creates a sort of neutrality. ${ }^{40}$ In order to dispose of heredity, it is necessary to have an excellent constitution. Montesquieu knew this; under the pressure of despotism there is a terrible leveling equality." 41 The supposed neutrality of the aristocratic class was closely linked with their judicial role in the House of Lords and the parlements. Generating a neutral power that could take the place of the hereditary class was a long-term preoccupation of Constant's constitutional thought.

Constant agreed that a monarchy depended on an aristocracy in order to protect freedom; he differed from Montesquieu in insisting that the reverse was also true (a monarch might check the local tyranny of lords) and in maintaining that this provided an argument against monarchy altogether. He thought that the benefits of the ancient constitution's division of pow-

39. This was, of course, the direction Constant's own arguments would lead him years later in "The Liberty of the Ancients Compared with that of the Moderns."

40. The supposed neutrality of the aristocratic class was closely linked with their judicial role in the House of Lords and the parlements. Generating a neutral power that could take the place of the hereditary class was a long-term preoccupation of Constant's constitutional thought.

41. Constant ([1810] 1991, 118). 
ers and classes could be simulated in an extended and federal republic; but he certainly agreed with Montesquieu that there had been such benefits. In the defenses of provincial and parlementaire rights and privileges, the ancien régime French conducted debates and engaged in struggles in which "everyone's heads were filled with the principles of liberty." 42

When Constant advised Bonaparte on the creation of a new constitution during the Hundred Days, he argued (against Bonaparte's inclinations) in favor of a new hereditary aristocracy. The emperor did not wish to be challenged, and in any event had no suitable candidates - the traditional aristocrats were his enemies. Constant, however, called a hereditary aristocracy "indispensable" for a constitutional monarchy. He would certainly have rather had a republic with no hereditary distinctions; but after the republic fell, there was a need for an aristocracy to moderate the imperial monarchy. He hoped to prevent the reemergence of feudal privileges, but to create a hereditary house parallel to the House of Lords.

In the Memoirs sur les Cent-Jours, there is a passage that begins much the same way, reporting the same arguments of Bonaparte against an aristocracy. But now Constant says that his longstanding doubts about a monarchy without an aristocracy had likely arisen because he, like Montesquieu, was "seduced" by the example of the British constitution. Here Constant himself criticizes the creation of a new, imperial, aristocracy - but not on rationalist or egalitarian grounds. Instead, he maintains that "nothing is created by artifice" in politics. "The creative force in politics, like the vital force in the physical world, cannot be supplemented by any act of will or by any act of law", ${ }^{43}$ rather, the spirit of the age and of a people would in some important way shape political developments and institutions. This is a Montesquieuian critique of one of Montesquieu's doctrines, and returned Constant to one of the themes of $S C U$-Bonaparte's status as a usurper, the inability to create new bloodlines and institutions and traditions from scratch that would have the same legitimacy as those that had come before. It moreover recalls the comment that it would be irrational to deliberately create the diversity in local laws, weights, measures, and so on that Constant defended in his chapter on uniformity.

In other words, Constant was torn between two Montesquieuian impulses. He perceived the need for an intermediate and independent body of aristocrats to balance the Emperor; but such a body would be a deliberate and artificial creation, out of keeping with the spirit of the nation and of the age. In his later writings and political work under the Restoration it seems to me that we can see the same dynamic. The social background, the spirit of the society in which Constant lived, was one that had been shaped by 
the Revolution and what followed it. Counter-revolution no more appealed to him in the 1820s than it had in the $1790 \mathrm{~s}^{44}$ - and in both decades one of his arguments against counterrevolution was that it would be at odds with changes in social character that had taken place. He argued that reforms should not outpace social change and that customs should be allowed to evolve freely without being coercively rushed by the state, but also, and for the same reasons, that political reactions should not attempt to undo social change that has already taken place.

Constant never supported the particular group privileges of the ancient constitution. He was keenly aware of the costs to individual freedom of statesanctioned group privileges. Constant's pluralism had to differ from Montesquieu's, however much he admired his predecessor; the post-revolutionary world he inhabited differed too greatly from the ancien régime. But he was far from certain about whether a society made up only of individuals and voluntary associations could keep centralization at bay. In his more optimistic moments he hoped that revitalized federalism or local self-government overlaid on a population with substantial provincial and local sentiment could provide the "germ of resistance" with a political vehicle without formal group-differentiated privileges, and that a literate and enlightened population with the franchise could check despotism. But sometimes, even late in his life when his hostility to contemporaneous Restoration nobles was at its height, he looked back to the institutions Montesquieu defended and the energy that privilege provided to resistance, and wondered.

Formerly, in all European countries there were institutions associated with many abuses but which, by giving certain classes privileges to defend and rights to exercise, kept up activity among these classes and thus preserved them from discouragement and apathy. To this cause must be attributed the energy of character existing up to the sixteenth century, an energy of which we no longer find any trace by the time of the revolution which shook thrones and reforged souls. These institutions had been everywhere destroyed, or changed so much that they had lost almost all their influence. . . . [D] efective institutions which nevertheless invest some powerful classes with certain privileges they are permanently interested in defending possess many disadvantages, yet they also possess the advantage of not letting the whole nation be degraded and bastardized. The beginning of Louis XIV's reign was disturbed by the Fronde, in truth a childish war, but one which was the remnant of a spirit of resistance accustomed to action, and still acting almost without purpose. Despotism greatly increased around the end of that reign..$^{45}$

In this he anticipated questions that would be of central concern to his successor as the intellectual leader of French liberalism, Alexis de Tocqueville.

44. Constant, "Des Réactions Politiques" (1797) in Louandre (1874).

45. Constant ([1822-24] 2015, 45, 51). 


\subsection{Tocqueville: Is the Art of Association Enough?}

One might think that it is in Tocqueville above all that we would find an appreciation of a pluralism that arises out of freely formed voluntary associations. He was, after all, the theorist of the "art of associating," the one who saw and appreciated the Americans' ability and eagerness to be "freely and constantly forming associations" both in political life and in the pursuit of their various social ends. Even his understanding of the structure of American government was associational; he was less struck by federalism and the extent of state authority than he was by self-government in townships-a level of political organization he explicitly referred to as an "association."

He witnessed phenomena in American society that one might think solved the problem of pluralism without privilege: a social sphere of free and open associational creation, entry, and exit. As Tocqueville understood it, the associational world he found among the Americans differed from ancien régime pluralism among the corps not only by its equality but also by its fluidity. The corps were longstanding; Americans had mastered the art of associating anew, creating new associations easily, almost casually, for reasons great or small.

Tocqueville identified one root of this art in the American inheritance from English dissenting Protestantism, but perhaps overlooked others in the new American models of economy and law. Eighteenth- and early nineteenthcentury uses of the phrase "civil society" referred mainly to the development of what was also called commercial society, and also to the modern unified legal system that underlay commercial society. Civil society replaced the world of privilege - including trading companies with monopolistic privilege, churches with ecclesiastical jurisdictional privilege, and nobles with status privilege - with a unified free and equal legal system. This system encompassed importantly laws governing commercial exchange, such that Hegel identified "civil society" with the open market and Marx dismissed it as bourgeois civil society. It was just such an open-access legal regime - associated with the move toward a democratized law of commercial incorporationthat allowed for the associational world Tocqueville saw, the associational world to which we most often reserve the phrase "civil society" today.

Yet, as with Smith and Constant, matters are not so simple, and Tocqueville cannot simply be read as celebrating an order of competitive associational life. The animating concern of Tocqueville's two greatest works is that the conjoined historical movements toward equality and centralization will leave despotism impossible to resist and freedom impossible to defend. $\mathrm{He}$ was clear in Democracy in America that his concerns were either European or universal, not narrowly American (though the American canonization of Tocqueville is prone to overlook this). In the penultimate chapter of volume 1, he refers to both the mores that once kept government limited, and to the institutions that did so such as 
the prerogatives of the nobility, of the authority of sovereign courts, of the rights of corporations, or of provincial privileges, all things which softened the blows of authority and maintained a spirit of resistance in the nation ... political institutions which, though often opposed to the freedom of individuals, nevertheless served to keep the love of liberty alive in men's souls with obviously valuable results. ... When towns and provinces form so many different nations within the common motherland, each of them has a particularist spirit opposed to the general spirit of servitude; but now that all parts of a single empire have lost their franchises, usages, prejudices, and even their memories and names and have grown accustomed to obey the same laws, it is no longer more difficult to oppress them all together than to do this to each separately. ${ }^{46}$

Here we see not only a précis for his study of the French old regime decades later, we also find by implication the animating questions of Democracy in America itself. Have the Anglo-Americans so far avoided this descent into servility? If so, how, and what can be learned from them about how to maintain liberty in a democratic age? In old regime France he saw the gradual erosion of intermediate bodies by a centralizing and homogenizing power that became almost irresistible as it aligned with the world-historical force of democratization. In the France of his own day he saw what he took to be the direction of the modern world: democratic equality and statist centralization reinforcing each other and grinding down freedom, distinctiveness, and accomplishment. In contemporaneous America he saw a democratic society that was resisting these trends, in part thanks to local government and to voluntary associations. But in the American future he saw the possibility of "soft despotism" of homogeneous mediocrity and centralized bureaucratic paternalism. While American associations (including the township) allowed for collective action in an egalitarian age when the individual actor was impotent, they were still small and powerless relative to the bureaucratic state or the democratic majority behind it.

While both Democracy in America and The Old Regime and the Revolution offer famously complex and multicausal accounts, group life and decentralized government figure prominently in each. The Americans benefited from their institutions of local self-government and from their mania for forming voluntary associations. And the French old regime, by the time of the Revolution, was ready to collapse into a democracy that eventually yielded Bonaparte's despotism in large part because the Bourbon kings had centralized the state so dramatically, undermining urban liberty, provincial liberty, and the privileges of the corps so effectively.

Tocqueville described medieval Europe as being everywhere much the same, with provincial liberties and urban self-government coexisting with feudal privileges and assemblies of the Estates. But — and this is the central 
thesis of Old Regime - that shared order was eroded and replaced by a centralized state gradually over the course of early modernity, not suddenly by the Revolution. By the eighteenth century, "the ancient constitution of Europe" was "half-ruined everywhere" 47 and no longer able to check absolutist monarchs. At the highest level of abstraction, Tocqueville attributes this to the increasing equality of condition over the later Middle Ages and early modernity, a change in historical stage from feudal inequality to democratic equality. "The nobles were already beaten down and the people had not yet risen; the former were too low and the latter not high enough to hinder the movements of power." ${ }^{48}$ Germanic customary law had been supplanted by Roman civil law, a "law of servitude," opportunistically deployed across the continent by monarchs set on establishing their "absolute power" "on the ruins of the old liberties of Europe." ${ }^{49}$ Tocqueville offers a history of royal suppression of provincial liberties, of urban self-government, and of guild and corps privileges, as well as of the deliberate Bourbon undermining of the social role of the nobility.

The decayed institutions of the eighteenth century created a paradoxical situation for the old regime. On the one hand, they were unloved, indeed, often detested. A nobility that no longer had any useful purpose in the countryside retained feudal privileges and immunity from taxation, and the wealthy urban classes naturally resented them for it. Moreover, they served to divide people against each other. While all were becoming more alike in social fact, they remained sharply legally and politically differentiated, and mutual antagonism resulted. But such freedoms as remained, such limits on royal absolutism as still existed, were thanks to these unloved institutions. They "preserved the spirit of independence among a great number of subjects, and inclined them to stiffen their necks against abuses of authority." ${ }^{50}$

And so Tocqueville emphasized the role of the prerevolutionary corps intermédiaires, at the same time that he described the inevitability of their decline. Like Montesquieu and Constant before him, he acknowledged their privileges and prerogatives to have been often "odious in themselves," and he thought that they became progressively more intolerable as French society became leveled and homogenized. The esprit de corps found in the nobility, the clergy, the lawyers, and each city's bourgeoisie, their commitment to the group's privileges and rights of self-rule, provided them with both the motive and the means to resist royal despotism.

About the parlements in particular, Tocqueville thought much as Constant had; their role in government "was a great evil which limited a greater one." Tocqueville wrote admiringly about the parlementaires' resolve dur- 
ing the dissolution of the Parlement of Paris in 1771. All of them accepted their loss of status "without a single one of them personally surrendering to the royal will," inspiring other judges and lawyers to stand with them and refuse to cooperate with this suspension of legality. However socially unjust their position was, the parlementaires proved themselves to be courageous and committed defenders of liberty and the rule of law: "I know of nothing greater in the history of free nations than what happened on this occasion." 51

\subsection{The Open-Access Order and Civil Society}

North, Wallis, and Weingast analyze the "doorstep conditions" for the transition from limited-access to open-access orders in terms of impersonality and equality. This means, among other things, that elite privileges and power politics be transformed into common, impersonal rights for members of the elite, subject to the rule of law; and that among these elite rights is the right to create perpetually lived impersonal corporate organizations. Crossing the threshold consists in part in extending the right to those legal and organizational resources to nonelites. Privilege and personality give way to equal-access pluralism.

In Tocqueville's analysis of the behavior of the parlementaires and their supporters, we can see that even within the doorstep stage, there might be tensions among these desiderata. The parlements defended the rule of law among elites in ancien régime France, they did so from a position of personal aristocratic privilege, and their status-oriented, personalistic willingness to defend their status provided crucial motivation for them to act in defense of the rule of law. Members of the corps of the parlementaire nobility and members of the lawyers' guild were willing to act oppositionally, standing against the crown in defense of their status and prerogatives. And on the other side of the Revolutionary transition, in the midst of France's step across the threshold into an open-access order, Tocqueville worried that without this motivational energy, opposition would be lacking. This, it seems to me, is the kind of thought that runs through these pluralist liberals across the transition from the mature natural state to the early open-access order.

In order to bridge the gap between the mid-nineteenth century and contemporary social theory, I suggest that we return to Ernest Gellner's model of civil society mentioned earlier. We might fairly read Gellner's post-1989 writings on liberal democracy as, in part, a celebration of open-access orders. ${ }^{52}$ While he did not anticipate the North, Wallis, and Weingast arguments in full, he shares their emphasis on the character of associational and organizational life, the impersonality of the state, and access to political resources including military power. And he sees this order as crucially 
individualistic — not in the sense that in civil society we lack associations, but in the sense that these are merely associations, nothing thicker or deeper.

"Modular man," Gellner wrote of his ideal-typical inhabitant of civil society, "is capable of combining into effective associations and institutions, without these being total, multi-stranded, underwritten by ritual and made stable through being linked to a whole inside set of relationships, all of these being tied in with each other and so immobilized. He can combine into specific-purpose, ad-hoc, limited associations, without binding himself by some blood ritual." 53

Gellner insists that the organizational triumph of the modern state over its medieval predecessors was one precondition for the emergence of a truly civil society, one in which associations may be formed, and exited, at will. This eliminates the potency of group ties to shape access to political and military power because the nation-state has trumped all substate competitors. Gellner's unified account depicts a social world of equal liberal agents creating new voluntary associations as easily, and with the same rules, as they create economic firms or political parties. This is an idealization of the open-access order - a strange word to use for a thinker so chastened as Gellner, but I mean it both in the sense that it is a Weberian ideal type and in the sense that it was, by Gellner's own moral lights, normatively ambitiously better than really existing open-access orders.

But it is important to note that Gellner's image of civil society fit neatly with his functionalist account of the emergence of nationalism; indeed, he insisted that "modular man is a nationalist." ${ }^{54}$ Workers in an industrial economy shed guild identities and inherited employment, and need a modular education that will allow them to perform a variety of jobs in a variety of industrial workplaces. This in turn requires a nationally homogenous language in which workers can become literate, so that they might move around the country in response to labor needs and work alongside those whose ancestral dialects might have been incomprehensible to them. In other words, so that individual persons might be able to equally access the labor opportunities in a modern economy, premodern, ethnocultural, regional, and linguistic differences must be overcome. The affinities between the industrial firms in this story and the associations in his depictions of civil society are not a coincidence.

While Gellner thought it a kind of virtue that modular man is a nationalist, these nation-building projects of modern states were just the kind of centralizing pursuits of uniformity that so worried the eighteenth- and nineteenth-century pluralist liberals. ${ }^{55}$ The increasingly unitary nation-

53. Gellner $(1994,99)$.

54. Gellner (1994, 103) and Gellner (1983).

55. While he lies beyond the scope of this essay, I would add Lord Acton to the theorists I have discussed here. See chapter 9 in Levy (2015). 
state, they feared, provided a very uncertain political home for liberal freedom, including the associational freedoms of civil society. Faced with what they took to be an underlying tendency for modern states (and, increasingly, nation-states) to become uniform and centralized, these theorists hoped that pluralism could be recovered without privilege. They regarded the republican terror of faction and disunity as pathological, and appreciated Montesquieu's diagnosis of centralization's evils, but saw that the corps could not and should not survive in a democratic age. But the kinds of pluralism they both sought to legitimize rested more than is often appreciated on ancien régime foundations. The more liberal freedom of association, religious freedom, and local government they hoped could replace the corps still depended on extralegal social pluralism for its energy. The horizontal competition of firms and associations, with persons joining and leaving them at will, lacks a mechanism for the vertical constitutional constraint of centralizing states. And the abolition of privilege, the democratization and opening of organizational life, the shift from nobles defending their honor or lawyers standing on their guild rights to "modular man" putting on and taking off associational identities, may make that oppositional energy hard to come by.

\section{References}

Appiah, Anthony. 2010. The Honor Code. New York: W. W. Norton.

Constant, Benjamin. (1804) 1957. “Journaux Intimes.” In Oeuvres, edited by Alfred Roulin. Paris: Gallimard.

- (1810) 1991. Fragments d'un Ouvrage Abandonné Sur la Possibilité d'une Constitution Républicaine Dans un Grand Pays, edited by Henri Grange. Paris: Aubier.

- (1810) 2003. Principles of Politics Applicable to All Governments, translated by Dennis O'Keefe. Indianapolis: Liberty Fund.

. (1819) 1988. "Liberty of the Ancients Compared with that of the Moderns."

In The Political Writings of Benjamin Constant, edited by Biancamaria Fontana, 324. Cambridge: Cambridge University Press.

(1822-24) 2015. Commentary on Filangieri's Work, translated and edited by Alan S. Kahan. Indianapolis: Liberty Fund.

Destutt de Tracy, Antoine Claude. (1811) 1969. A Commentary and Review of Montesquieu's Spirit of the Laws, translated by Thomas Jefferson. New York: Burt Franklin.

Fears, J. Rufus, ed. 1988. Selected Writings of Lord Acton, vol. I. Indianapolis: Liberty Fund.

Gellner, Ernest. 1983. Nations and Nationalism. Ithaca, NY: Cornell University Press. . 1994. Conditions of Liberty: Civil Society and Its Rivals. New York: Penguin.

Golemboski, David. 2015. "Federalism and the Catholic Principle of Subsidiarity." Publius 45 (4): 495-525.

Hirschman, Albert. 1970. Exit, Voice, and Loyalty. Cambridge, MA: Harvard University Press. 
Jennings, Jeremy. 2011. Revolution and the Republic: A History of Political Thought in France since the Eighteenth Century. Oxford: Oxford University Press.

Kalyvas, Andreas, and Ira Katznelson. 2008. Liberal Beginnings: Making a Republic for the Moderns. Cambridge: Cambridge University Press.

Krause, Sharon. 2002. Liberalism with Honor. Cambridge, MA: Harvard University Press.

Levy, Jacob T. 2006. "Beyond Publius: Montesquieu, Liberal Republicanism, and the Small-Republic Theses." History of Political Thought 27 (1): 50-90.

- 2007. "Federalism, Liberalism, and the Separation of Loyalties." American Political Science Review 101 (3): 459-77.

. 2015. Rationalism, Pluralism, and Freedom. Oxford: Oxford University Press.

Louandre, Charles, ed. 1874. Oeuvres Politiques de Benjamin Constant. Paris: Charpentier et Cie.

Montesquieu, Baron de. (1748) 1989. The Spirit of the Laws, edited by Anne M. Cohler, Basia Carolyn Miller, and Harold S. Stone. New York: Cambridge University Press.

. 2012. My Thoughts, translated by Henry C. Clark. Indianapolis: Liberty Fund.

North, Douglass, John Wallis, and Barry Weingast. 2009. Violence and Social Orders. Cambridge: Cambridge University Press.

Ostrom, Elinor. 1990. Governing the Commons: The Evolution of Institutions for Collective Action. Cambridge: Cambridge University Press.

Ostrom, Vincent, Charles M. Tiebout, and Robert Warren. 1961. "The Organization of Government in Metropolitan Areas: A Theoretical Inquiry." American Political Science Review 55 (5): 831-42.

Pocock, J. G. A. 1975. The Machiavellian Moment. Princeton, NJ: Princeton University Press.

Putnam, Robert D. 2000. Bowling Alone: The Collapse and Revival of American Community. New York: Simon and Schuster.

Rosenblatt, Helena. 2008. Liberal Values: Benjamin Constant and the Politics of Religion. Cambridge: Cambridge University Press.

Schmitter, Philippe C. 1974. "Still the Century of Corporatism?" Review of Politics 26 (1): 85-131.

Smith, Adam. (1776) 1981. An Inquiry into the Nature and Causes of the Wealth of Nations, edited by R. H. Campbell, A. S. Skinner, and W. B. Todd. Indianapolis: Liberty Fund.

(1790) 1981. Theory of Moral Sentiments, edited by R. H. Campbell and A. S. Skinner. Indianapolis: Liberty Classics.

Taylor, Charles. 1990. "Modes of Civil Society." Public Culture 3 (1): 95-118. . 1992. Multiculturalism and the Politics of Recognition: An Essay by Charles Taylor. Princeton, NJ: Princeton University Press.

1993. Reconciling the Solitudes: Essays on Canadian Federalism and Nationalism. Montreal, QC: McGill-Queen's University Press.

Tiebout, Charles M. 1956. "A Pure Theory of Local Expenditures." Journal of Political Economy 64 (5): 416-24.

Tocqueville, Alexis de. (1835/1840) 1969. Democracy in America, edited by J. P. Mayer. New York: Harper \& Row.

Tocqueville, Alexis de. (1856) 1998. The Old Regime and the Revolution, vol. 1, edited by François Furet and Françoise Mélonio, translated by Alan S. Kahan. Chicago: University of Chicago Press.

Ward, Lee. 2009. "Montesquieu on Federalism and Anglo-Gothic Constitutionalism." Publius: The Journal of Federalism 37 (4): 551-77. 
Weingast, Barry. 1995. "The Economic Role of Political Institutions: MarketPreserving Federalism and Economic Development." Journal of Law, Economics, and Organization 11:1-31.

Wood, Gordon S. 1969. The Creation of the American Republic, 1776-1787. Chapel Hill: University of North Carolina Press. 